DOI: 10.1515/ausfm-2015-0025

\title{
The Intermedial Cluster: Åke Hodell's Lågsniff
}

\author{
Per Bäckström \\ Karlstad University (Sweden) \\ E-mail: per.backstrom@kau.se
}

\begin{abstract}
Avant-garde aesthetic movements react on and appropriate new technological media in a process of breaking down the boundaries between different media and different "arts," in an attempt to generate meaning from the sheer materiality of the artwork. Avant-garde artworks will therefore by necessity be marked by media in different ways, at the same time as these art forms are processual, performative and transgressive. One of the prime Swedish examples of this avant-garde strategy is Åke Hodell's many realizations of his manuscript Lågsniff. The manuscript, written in 1963, was in the form of a text-sound-composition, which means that Lågsniff, already in this form, took many configurations with a plurality of genres and media modalities involved. Later the manuscript was realized as a series of performances, a TV-film, a book, and in 2002 as a DVD. For such a collection of art works, I would like to suggest the term "intermedial cluster." The point of departure for my discussion is the DVD, a remediation of the TVfilm from 1966, and I will focus on two of the juxtaposed discourses in the cluster that this DVD represents: the package tour and warfare, and on two thematic foci in the film: media and memory, and man as automaton.
\end{abstract}

Keywords: intermedial cluster, media, Åke Hodell, avant-garde, performance.

Avant-garde artists often focus on materiality and processuality in the creation of art, and as a result the avant-gardists are at the forefront when it comes to employing new technological media, with the consequence that the borders between different media and different arts are eroded. A case in point, exemplifying how the awareness of the contemporary media ecology can be framed in a "single" work of art, is the Swedish avant-gardist Åke Hodell's work Lågsniff (1963 and onwards). Hodell's work also illustrates how such awareness is expressed through different juxtapositions: of high art and popular culture; of art and life; and of the different mediations of this work (for example, from manuscript and performance to the final DVD) as well as within the piece itself (voice, code, noise etc.). To further elaborate on these different mediations, I will base my argument on the 
concept of media modalities as suggested by Lars Elleström: "I would say that all kinds of sign systems and also specific media productions and works of art must be seen as parts of a very wide field including not least the material, sensorial, spatiotemporal and semiotic aspects" (Elleström 2010, 4).

\section{Avant-Garde}

A second essential background to my discussion is the radical division between avant-garde and modernism, two of several aesthetic movements in the $20^{\text {th }}$ century, a separation that is evident when it comes to media and "low culture."1 Here, I want to relate to the "great divide" between high and low culture, which Andreas Huyssen (1986) suggests to be a distinguishing mark of modernism, while pointing out that the avant-garde tries to undo this divide in every way, since it is clearly under attack in Lågsniff. ${ }^{2}$ Richard Murphy elaborates on the difference between avant-garde and modernism in his book Theorizing the Avant-Garde (1999): "what distinguishes the avant-garde from modernism in general is its institutional awareness: firstly, unlike modernism the avant-garde not only renovates the means but also deconstructs the ideology of art, while reflecting upon those social demarcations of culture for which modernism seems to show a complete lack of awareness or interest. The avant-garde sets out to expose and alter art's status as a socially differentiated and segregated mode of discourse, and to make it clear that its position is always mediated by the social mechanisms responsible for the institutionalization of culture. [...] the avantgarde's goal of overcoming the enforced separation of art and life springs precisely from its insight into what Habermas defines [...] as the process of 'bourgeois rationalization' responsible for producing this functional differentiation of the separate spheres of social activity. For behind the avant-garde's eccentricities and seemingly meaningless antics in ridiculing, exposing and overthrowing art's rules lies a profoundly meaningful purpose: the interrogation of the historically specific means by which art is mediated and administered by society's dominant cultural discourses" (Murphy 1999, 258).

The avant-gardists distort - in a very concrete way - art and society in an attempt to understand them in relation to their own lives. And the different

1 While modernists of course use new media and technologies as well as low culture in their art, they do so only as means to create their art, while different avant-gardists use new media and low culture in a wish to achieve integration between art and life, in their investigation of life.

2 Even though Huyssens's "great divide" has been much discussed and also critiqued, the notion in itself does make certain differences between modernism and avant-garde clear. 
stands taken by the avant-gardes and modernism in popular culture here become distinguishing marks, as Murphy continues: "modernism for example responds to this disappearance of the 'original' and to the effacement of the real-life referent not only by differentiating itself sharply from the reified forms associated with consumerist mass culture and the commodity form (for example through its emphasis on the high cultural status of its hermetically distanced forms), but simultaneously compensates for the loss of 'aura' by reasserting with all the more vehemence the notion of newness, originality and artistic innovation - a response amounting in a sense to a new spin on the Classic-Romantic use of the concept of the 'genius.' By contrast, the artists of the avant-garde and postmodernism both respond to this development by taking the opposite tack: they present the 'referent,' the object itself, as both the 'referent' and its artistic 'representation' in one - paradigmatically in the 'objet trouvé' - thereby questioning not only the conventions of aura and of original artistic creation (as Bürger has shown), but also disclosing the overlaps already existing between the two levels of reference (referent-signifier), that is to say, the points at which these levels already begin to 'short-circuit' and explode the conventional artistic/representational system" (Murphy 1999, 269). To "short-circuit and explode the conventional representational system" indeed seems to be the real aim of the avant-garde, and this is especially true of the Swedish neo-avant-gardes in the 1960s.

One of the distinguishing marks of the Swedish avant-garde of the sixties is the relation between literature and media, as Jonas Ingvarsson points out: "In the Swedish literary climate of the sixties, the examples of the cross-fertilisation between literature and other technologies are obvious, especially in the second half of the decade. Concrete poets moved into the electro-music studios and the happenings staged by the young avant-garde at the Museum of Modern Art used tape recorders and amplifiers as tools, authors published 'prose machines,' and Göran Palm claimed in his unfair reflections in 1966 that his starting-point is the fact that he learned to 'travel with his sense organs' with the help of the transmitting media” (Ingvarsson 1999, unnumbered, my transl.). Here is the mixed media craze of the sixties, where language becomes one of many media, and art grows out of a wish to make a cross-aesthetic work, in line with what romanticism entitled Gesamtkunstwerk, but without the metaphysical implications of this age. 


\section{Lågsniff}

One of the prime Swedish examples of the avant-garde strategy mentioned is Åke Hodell's many realizations of his artwork Lågsniff. A manuscript was written in 1963 with the intention to be performed as a text-sound-composition, which means that it straight away crossed media borders and exposed the media modalities of the artwork at once. ${ }^{3}$ The manuscript in itself looks more like concrete poetry than a script for a play or performance, although scene instructions can be found in the text as well since, as mentioned, it was used as the basis of the later performances [Fig. 1]. Lågsniff was performed for the first time at the legendary Swedish Svisch-performance at the Museum of Modern Art in Stockholm on the $4^{\text {th }}$ of November, 1964, which was one of many avant-garde manifestations during the 1960s, and thereafter, in a slightly reworked version at the Pistolteatern in January 1965. It was recorded by the Swedish television on one of these occasions, and broadcast in December of the same year (Olsson 2005, 385). In 1966, Lågsniff also appeared as a book [Fig. 2], in combination with a record. And finally, the TV-film was digitalized and released as a DVD in 2002 [Fig. 3], a remediation that is crucial for the possibility to view the original film, which remains hidden in the archives of the Swedish radio and television.

This means that Lågsniff takes many configurations, with many genres and modalities involved, and for this compound of artworks I want to suggest the concept "intermedial cluster." Compared with the notion "remediation," which (put simply) concerns a transformation of an artwork from one media into another, the notion of "intermedial cluster" refers to different artworks that together form a larger, multifaceted artwork. ${ }^{4}$ It would have been extremely interesting to investigate in-depth the different works in this intermedial cluster in relation to each other to see how their modalities both interact and change depending on genre, but it is not possible within the scope of this article. ${ }^{5}$ I will therefore use

3 "Text-sound composition" is a notion proposed by the Swedish composer Lars Gunnar Bodin and the Swedish poet Bengt Emil Johnson to signify poetry that exists in the borderland between music and literature. The poetical artwork is based on recorded texts used both as pitch source and semantic material, often combined with electronic and concrete sounds.

4 The notion of "intermedial cluster" is even more necessary for phenomena such as land art, since, for example, Robert Smithson's Spiral Jetty (1970) is an artwork that consists of a variety of documentation material, sketches etc, but where the artwork itself no longer exists. The artwork Spiral Jetty, as it exists today, is therefore the intermedial cluster that this material forms.

5 Due to the complexity of this artwork and the extensive archival research that the study implicates, a profound analysis should result in a book or doctoral thesis. First of all, there are a great many different realizations of the manuscript, which alone demand more than the few pages 
the DVD as my basis for an illustration of how an intermedial cluster functions, while keeping the other genres in mind as well.

The Swedish word "lågsniff” is used by pilots to mean "low range flying." Åke Hodell himself was a combat pilot until he crashed with his plane in 1941, after which he spent several years in hospital, becoming a poet and a radical pacifist. The DVD-film is 20 minutes long, and many of the leading Swedish avant-gardists had a role in the single performance documented in the TV-film (released on DVD): Åke Hodell, Torsten Ekbom, Beng Emil Johnson and Leif Nylén. The Spanish poet mentioned in the play, Carlos Álvarez Cruz, had his works banned during the Franco-regime. The movie starts with the actors chatting about soccer in a café before they stroll to the theatre for the performance. They simulate an airplane take-off for a package tour to fascist Spain, with the audience acting as the naive tourists. During the performance, Hodell tries to read a poem by the Spanish poet, but is constantly interrupted by the white noise of the TV-medium, while Ekbom transmits the poem in Morse code without problem. Close to the end, the tourist flight is turned into a bombing mission before the plane lands safely on Mallorca.

The manuscript, the book, the performances and the TV-film all deal with the relation between different media and their modalities, especially media in the form of various technological apparatus. The intermedial cluster Lågsniff is too intricate to be discusseed here, as mentioned before, but also the DVD in itself is too complex to be discussed, which is why I will concentrate on two of the combined themes within this heterogeneous film: popular culture, exemplified by the package tour, and warfare; and on two thematic foci in the film: media and memory, and man as automaton.

The first theme in the film is the package tour, which was a new means of transport at the time. The avant-gardes in the sixties were very quick to pick up on this new popular culture of mass transportation, completed with songs from Spain. Actually, package tours are still seen as a popular phenomenon and not really an accepted way to travel according to high culture, which still insists on individual travelling or on high quality travel organizers who maintain a cultural capital. This is a highly clarifying example of the shifts between high and low in the art of the avant-garde.

Several attempts are made to make the audience part of the play, for example, at the beginning, the actors sit in a nearby café talking about soccer, a low culture

offered here for a comparison of the different modalities between different media; secondly, and worse, many of these realizations do not exist anymore, such as most of the performances (we only have a documentation of one of them left, a documentation that furthermore is edited into the TV-film and later digitalized for the DVD discussed above). 
sport, until they stroll to the theatre to do their "job;" or in the scene where the airhostesses, dressed as nurses, serve the audience chewing gums. ${ }^{6}$ In this way, the audience becomes part of the play, in accordance with the avant-garde intention of breaking up the barrier between audience and actors.

The second theme is war, both the - in 1963 - fairly recent Second World War and the acute cold war at the time. The manuscript was written only a year after the Cuban missile crisis and the risk of a total destruction of the earth and its population - as Hodell very interestingly put it in 1966: "Our world consists of errors in language and thought. The same word means different things in East and West. The technology of Gutenberg still dominates all political struggles for power and buttons in robot bases. I claim that if the world vanishes, it does so because of a language and thought error" (Hodell 2003, unnumbered). ${ }^{7}$

Hodell was a political artist, who protested against war, the military and politics in his poetry, plays and other arts. He had seen at close distance what war does to people and what people can do to each other in totalitarian states - as well as in Sweden. As Torsten Ekbom writes: "The military drill, the brainwash that transforms humans into robots, the technological systems that outgrow the human being, the anonymity of dying in the total war - the ethical perspective will always be in focus for Hodell” (Ekbom 1995, 225, my transl.). In Lågsniff, this is thematized, among other things, in the airhostesses dressed as World War Two nurses, and the package tour to Spain turning into a bombing mission where the tourists are associated with a bomber crew, i.e. are given responsibility for the repression and terror in Spain.

\section{Media - Memory}

Different forms of modern technological media have a very central role in this play. Actually, without broadcasting and storage media, there would have been no play at all, since - in a very literal sense - we could not have seen it at all today without Swedish television and the preserved tape that was converted into a DVD.

Åke Hodell was ambivalent about technology. He disliked commodification and commercialism, which he saw as means of power. He was aware of the fact that new technology penetrated every possible part of human life, which then could not be undone. And at the same time he was fascinated by the technology that gave him the means of experimenting.

6 When I saw the film for the first time, I associated the handing out of chewing gums with the dealing out of drugs, which would have been appropriate to the Zeitgeist, and to a more general idea of travelling.

7 Originally published in the Danish little magazine ta' no. 1, 1967, p. 18, printed in Swedish. 
Discussing the new avant-garde and its ability to react on new media, Torsten Ekbom observes: "It is the artist who will have to teach us how the media function, either by using the old media in a new way by creating hybrid forms between different media, or by working directly with the new media" (Ekbom 1966, cited from Ørum 2005, 314). Leif Nylén also describes the avant-gardists' fascination with technology: "But the aspect of technology that primarily attracted the young and experimental artists was the new media: as tool, object and a means of distribution. With Marshall McLuhan, the interest in the media was thus ascribed a kind of cultural philosophical foundation" (Nylén 1998, 133, my transl.). From this testimony by one of the avant-garde artists in the sixties, it is clear that Marshall McLuhan, especially through his book Understanding media (McLuhan 1964), was one of the most important thinkers for the Swedish neo-avant-garde. ${ }^{8}$

One should also be aware of the democratic impulse in the avant-garde aesthetics, something that we can also see implicitly in the play, in the constant disruptions of Hodell's reading of the jailed Spanish poet Carlos Álvarez, while the poem is easily transmitted in Morse code. But this also illustrates a very important observation by Friedrich Kittler, concerning the connection between the new technology and memory. He writes: "Technology triumphs over mnemotechnology. And the death bell tolls for poetry, which for so long had been the love of so many. In such circumstances writers are left with few options. They can, like Mallarmé or Stefan George, exorcise the imaginary voices from between the lines and inaugurate a cult of and for letter fetishists, in which case poetry becomes a form of typographically optimized blackness on exorbitantly expensive white paper: un coup de dés or a throw of the dice. Or for marketing reasons they can move from imaginary voices [...] to real ones, in which case a poetry of nameless songwriters appears, or reappears, on records. Illiterates in particular are their prime consumers, because what under oral conditions required at least some kind of mnemotechnology is now fully automatized" (Kittler 1999, 80).

The poetry of the jailed poet is cut in pieces, and the reading soon takes the nonsensical character that Kittler continues to write about: "Mechanization relieves people of their memories and permits a linguistic hodgepodge hitherto stifled by the monopoly of writing. The inrules governing rhyme and meter that Wildenbruch employs to arrange his words when speaking into the phonograph; the general concepts that Stransky's colleagues use to arrange theirs during the

$8 \quad$ Marshall McLuhan was rapidly introduced and translated into Swedish in the little magazine Gorilla in 1966. 
first test runs - Edison's invention renders them all historically obsolete. The epoch of nonsense, our epoch, can begin. This nonsense is always already the unconscious. Everything that speakers, because they are speaking, cannot also think flows into recording devices whose storage capacity is only surpassed by their indifference" (Kittler 1999, 86).

Hodell reads the Spanish poetry with a certain emotional expression, in spite of the fact that he is reduced to the role of a talking head, but is constantly interrupted by the "white noise" of media [Fig. 4]. The poem is left to the indifference of media, i.e. translated into Morse code, which is not easily understood by nontrained listeners. At the same time, one can note that Hodell repeatedly stops in his reading and starts to repeat what he has already said; the words do not want to come out, they get stuck in his mouth. This effect can hardly be conceived without new media such as the gramophone and the new editing possibilities in the tape recorder. In the poetry of Åke Hodell, there is a thematization of the conflict between language and reality. If the close and painful reality was put into a poem, the traditional poetical norms must be exploded. When the verses in Álvarez's poem are distorted by jamming and sabotage, it is on the one hand a picture of the conditions of Franco's tyranny in Spain, and on the other, an attack on the tradition of emotional and "high" poetry.

\section{Man as Automaton}

The attack on "high" poetry, however, should not be seen as a "deconstruction," but rather as a constructive process. The avant-garde of the sixties is not as nihilistic as Dada; instead, they present an alternative, as Torsten Ekbom points out: "The eighties deconstructed society. The sixties were rather preoccupied with constructing it" (Ekbom 1995). In their construction of reality, (technological) media is to a high degree an integrated part of the process, both as a means to create art and as extensions of the body, while the posthuman being is conceived of as an automaton, a machine in line with other machines.

In the play, all the participants behave in a rather mechanical way. The actors arrive at the theatre, inspect their technological equipment and start to act. The most striking example of this mechanical behaviour is when they perform machine noise [Fig. 5]. They have become machines, demonstrating interest in machines in the epoch when the human being was experienced as an extension of the machine - in line with the earlier quotation from Hodell. Kittler notes that this has its roots in a change of how we perceive communication technologies: 
"Nietzsche's notion of inscription [...] has validity only within the framework of the history of the typewriter. It designates the turning point at which communications technologies can no longer be related back to humans. Instead, the former has formed the latter" (Kittler 1999, 211). Preoccupation with the new media in the avant-garde art of the sixties does come out of an understanding of the human being as part of a nest of technological extensions. Man is no longer in control of the machine, but shaped by it.

\section{Conclusion}

A discussion about Hodell's different realizations of Lågsniff is by necessity intermedial in its character; but to strengthen my analysis, I want to return to Lars Elleström's modalities because what we see thematized in all the versions of Lågsniff is actually the four modalities of media: material, sensorial, spatiotemporal and semiotic. First of all, the DVD clearly points to both its material and technological character; particularly the specific use of codes, noise and technological sounds show how the materiality of the different media is in focus. Secondly, the sensorial comes into play - especially in the performed text - not only through visual and aural sensations, but also through the smell, taste and feeling experienced by means of chewing gums and loudspeakers, where amplifiers give the audience a direct bodily experience of noise. So, even though the DVD has its limitations, the play works on all five senses. Thirdly, the spatiotemporal could not be better put into "play" than through a rather short tour in a confined airplane, an event clearly marked by a beginning and an end; but this spatiotemporality is also violated when the package tour turns into a bombing mission, thus marked by its own historicity. Finally, the different semiotic systems in the play are highly in focus; not only that ordinary language plays a great part, but so do other semiotic systems which contribute to the production of meaning: noise, white noise, code languages, onomatopoetical renderings of technological sounds and the Morse code, which is the only system that survives throughout the greater part of the play. These different noises, sign systems and codes produce meaning in the film - in the same way that Sami Sjöberg has shown to be valid for the use of visual apostrophes in lettrism (Sjöberg 2010) -, and therefore partakes not only in the material mode of the medium but also in the semiotic one. The avant-garde highlights the modalities of the medium in its art works - they so to speak lay their devices bare -, thereby estranging the audience from the play itself while giving them a rather unusual experience. 
At the beginning of this article, I mentioned how Lågsniff displays awareness of contemporary media ecology, and here, I want to relate to some important questions that this ecology proposes. What do we hear and see in Lågsniffs different appearances? And how do we approach a work of art in the age of digital reproduction? It is clear that the transformations from a typewritten manuscript that adheres more to the genre text-sound-composition than a theatrical play into the play or performance itself at the Museum of Modern Art and the Pistolteatern in Stockholm, into the TV-film which was broadcast in 1965 and then nearly forgotten, into the book and record published in 1966, and finally, into the digitalized version put on DVD in 2002 form the intermedial cluster Lågsniff. The specificity of this cluster is that many of the different realizations are lost forever (the different performances) or very hard to access (the original manuscript and the TV-film), which sets the frame for our experience of it, since what we do see is an edited version of a singular performance with all the restrictions a film puts on what was once something experienced as "Hier und Jetzt" (with Walter Benjamin's formulation concerning the aura, in Benjamin 2010).

So, what do we see in the different versions, in the different genres, and what is actually the artwork itself? The answer is that the intermedial cluster does not consist of one of the versions, but is built on all the versions together. The intermedial cluster requires us to rearticulate the notion of "artwork" into the art works, a phrasing that better reflects the avant-gardists focus on the performativity and processuality of an artwork. The TV-film is only one version of this act, heavily mediatized by the TV-medium itself - with TV disturbances instead of noise when Hodell is interrupted etc. ${ }^{9}$ And the DVD is a weak copy of the film, since a digitalization consists, among others, of compression that reduces the contrast, the audio range etc. It is therefore crucial to understand that the different versions do not simply exist as diverse documentations of the highly sophisticated artwork the performance once was, but form the intermedial cluster Lågsniff in toto.

\section{References}

Auslander, Philip. 2008. [1999] Liveness. Performance in a Mediatized Culture. London and New York: Routledge.

Benjamin, Walter. 2010. The Work of Art in the Age of Its Technological Reproducibility. Grey Room no. 39: 1-37.

$9 \quad$ Mediatized in the meaning of permeated by (technological) media, as suggested by Philip Auslander (2008). 
Ekbom, Torsten and Bengt af Klintberg eds. 1989. Cabaret Hodell. En vänbok. [Cabaret Hodell. A Festschrift], Stockholm: Författarförlaget Fischer \& Rye. Ekbom, Torsten. 1995. Bildstorm. [Image Storm], Stockholm: Bonnier.

Elleström, Lars. 2010. The Modalities of Media. A Model for Understanding Intermedial Relations. In Media Borders, Multimodality and Intermediality, ed. Lars Elleström, 11-48. Basingstoke and New York: Palgrave Macmillan.

Hodell, Åke. Friends of the Bumblebee, CD, Håll Tjäften - TJÄFT 002, 2003.

Hodell, Åke. 2002. Lågsniff, DVD. Håll Tjäften - TJÄFT 001.

Hodell, Åke. 1966. Lågsniff. Stockholm: Rabén \& Sjögren.

Huyssen, Andreas. 1986. After the Great Divide. Modernism, Mass Culture, Postmodernism. Bloomington and Indianapolis: Indiana University Press.

Ingvarsson,Jonas.1999.Seeberg/Cyborg. Svenskt60-talochdenmediaimpregnerade prosan. [Seeberg/Cyborg. Swedish '60s and the Media-Impregnated Prose], Human IT. Tidskrift för studier av IT ur ett humanvetenskapligt perspektiv, no. 1, unnumbered.

Kittler, Friedrich. 1999. Gramophone, Film, Typewriter. Geoffrey WinthropYoung and Michael Wutz, transl. Stanford: Stanford University Press.

McLuhan, Marshall. 2002 [1964]. Understanding Media. The Extensions of Man. London and New York: Routledge.

Murphy, Richard. 1999. Theorizing the Avant-Garde. Modernism, Expressionism, and the Problem of Postmodernity. Cambridge: Cambridge University Press.

Nylén, Leif. 1998. Den öppna konsten. Happenings, instrumental teater, konkret poesi och andra gränsöverskridningar i det svenska 60-talet. [The Open Art. Happenings, Instrumental Theatre, Concrete Poetry and Other Transgressions in the Swedish '60s], Stockholm: Sveriges allmänna konstförening.

Olsson, Jesper. 2005. Alfabetets användning. Konkret poesi och poetisk artefaktion i svenskt 1960-tal. [The Use of the Alphabet. Concrete Poetry and Poetic Artifice in Swedish '60s], Stockholm: OEI editör.

Sjöberg, Sami. 2010. Media on the Edge of Nothingness. Visual Apostrophes in Lettrism. In Media Borders, Multimodality and Intermediality, ed. Lars Elleström, 124-134. Basingstoke and New York: Palgrave Macmillan.

Ørum, Tania. 2005. Means and Metaphors of Change. Technology and the Danish Avant-Garde of the 1960s. In Avant-Garde/Neo-Avant-Garde, ed. Dietrich Scheunemann, 311-324. Amsterdam and New York: Rodopi. 


\section{List of Figures}

Figure 1. A page from the manuscript Lågsniff, 1964. (Torsten Ekbom and Bengt af Klintberg 1989, 47.)

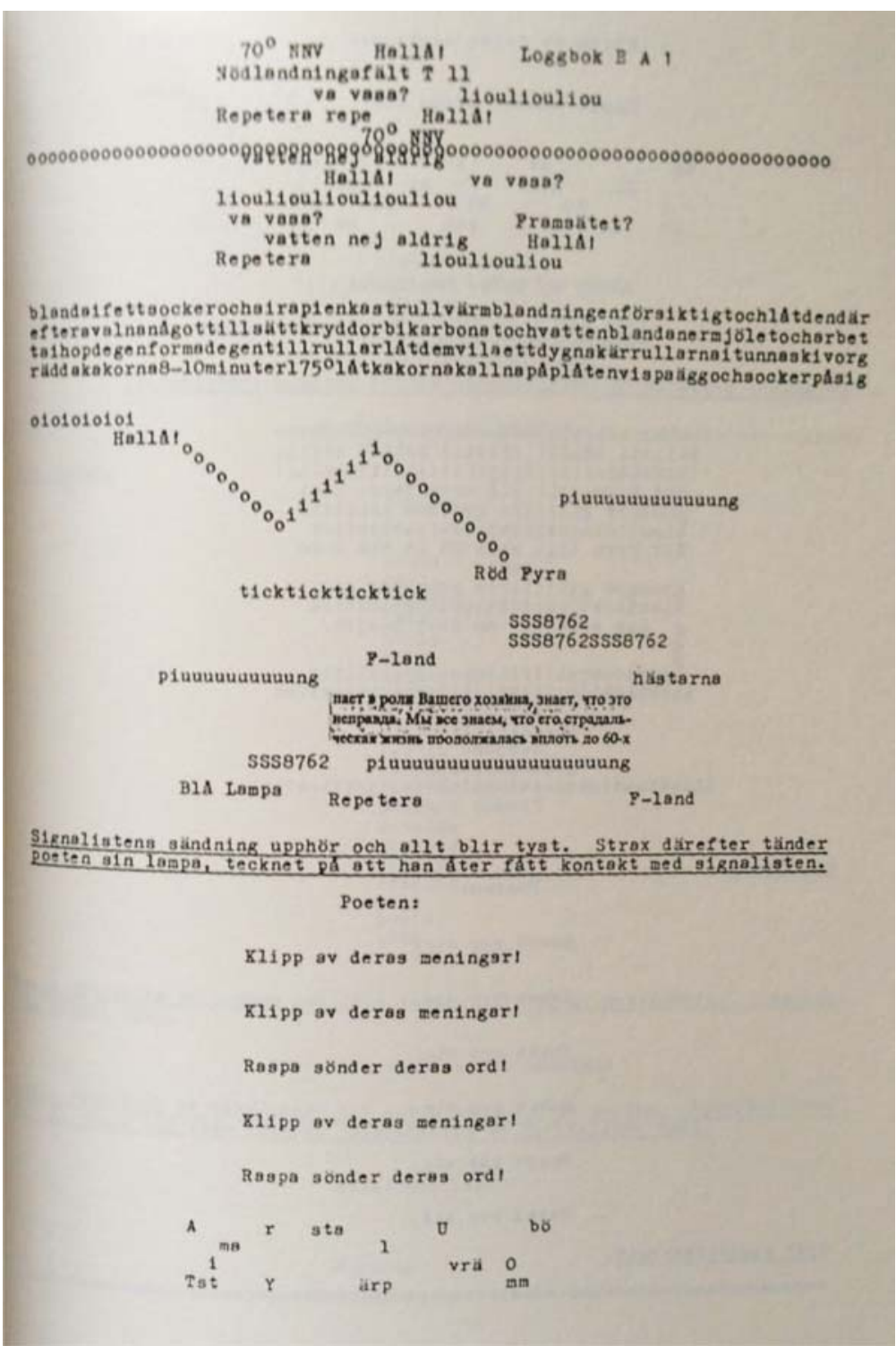


Figure 2. The printed book Lågsniff, 1966.

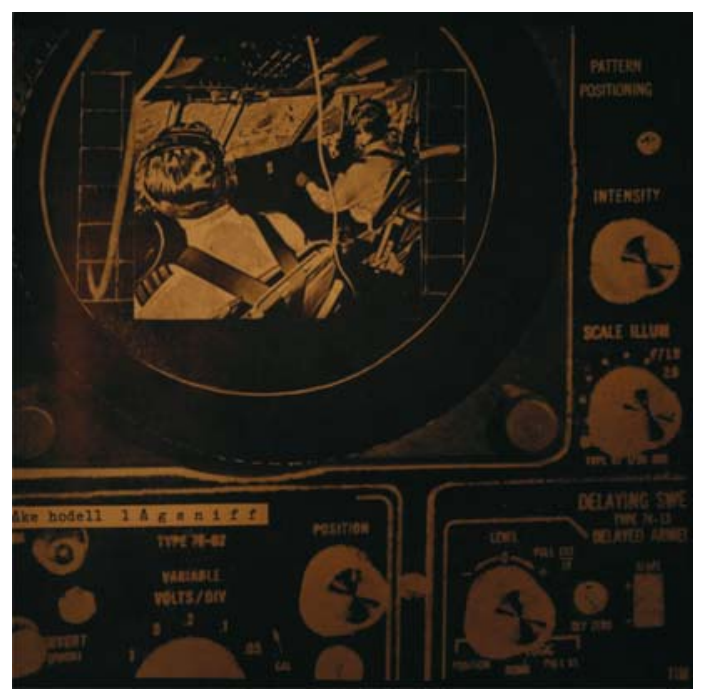

Figure 3. The cover of the DVD Lågsniff, 2002.

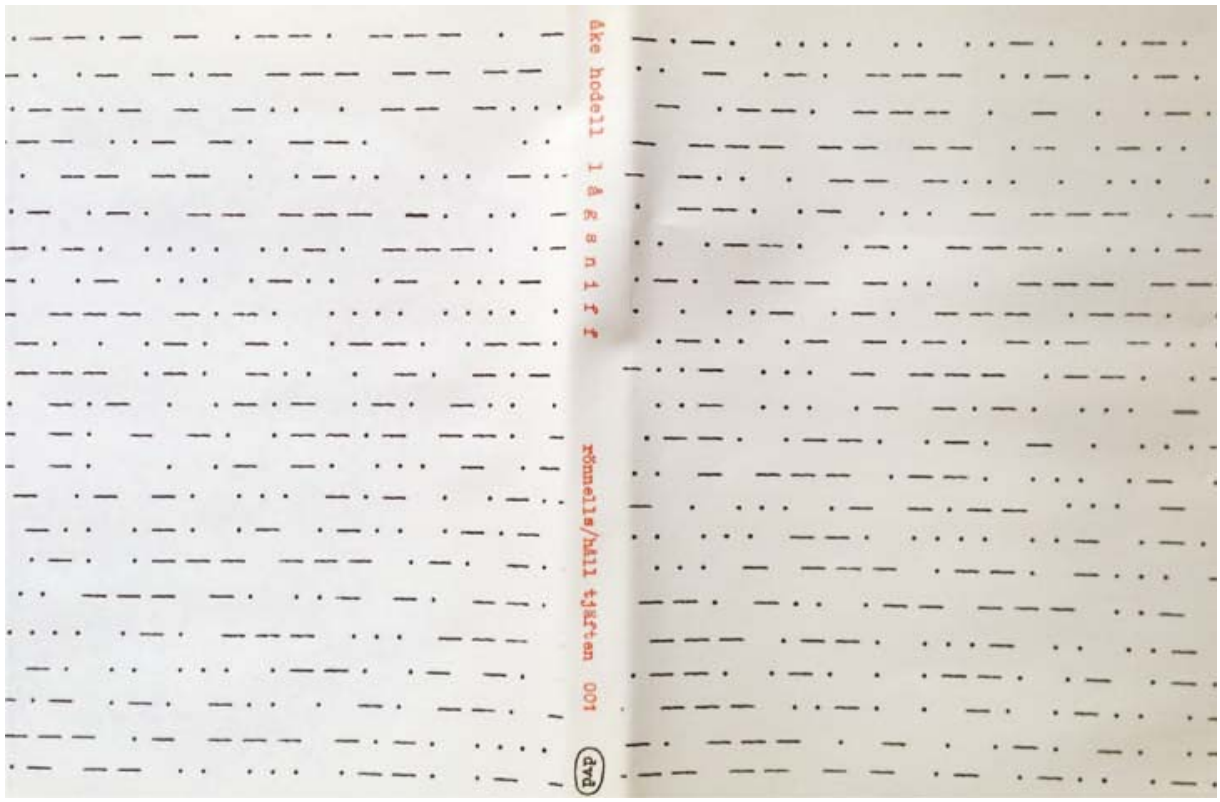


Figure 4. Åke Hodell performing Lågsniff.

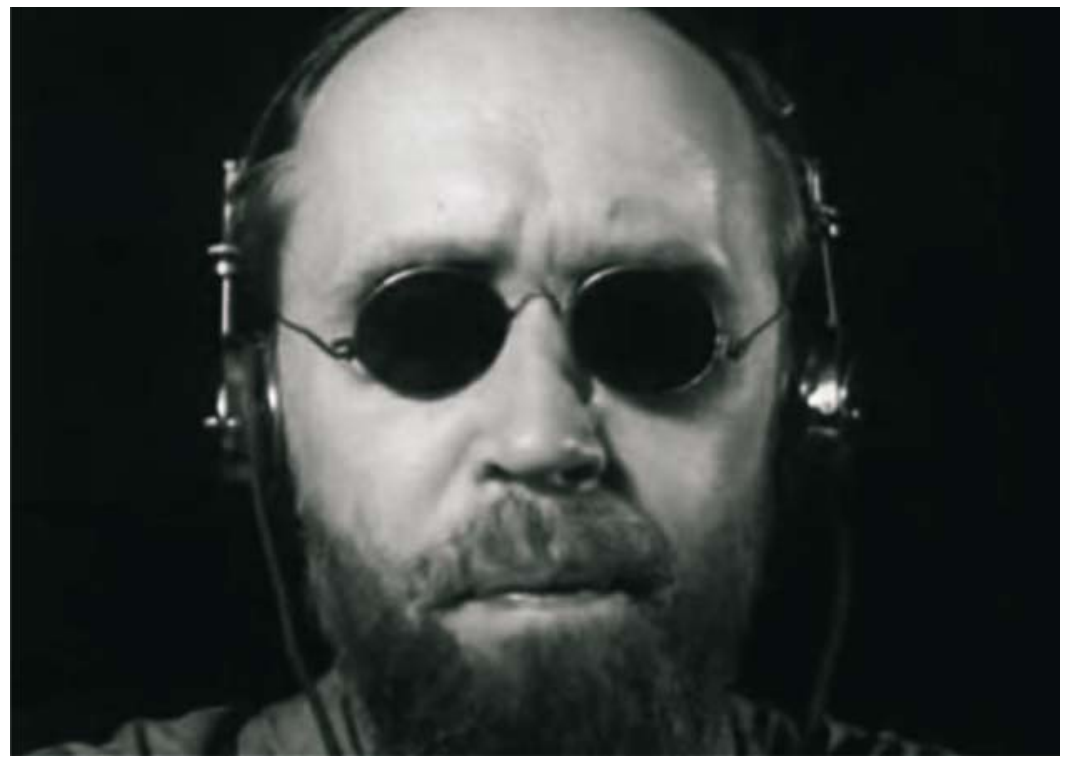

Figure 5. Leif Nylén performing Lågsniff.

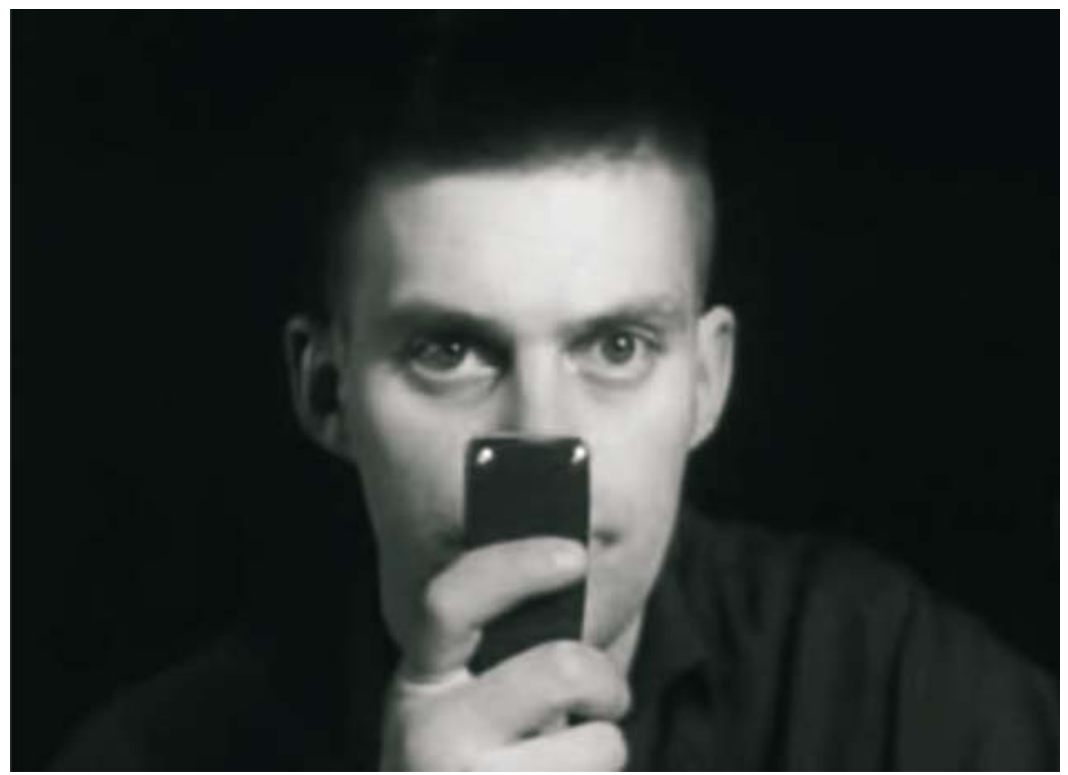

